\title{
Pengaruh E-WoM terhadap Customer Engagement Osbond Gym Bekasi dalam Penerapan Protokol Kesehatan Covid-19
}

\author{
Vendy Octavian, Wulan Purnama Sari \\ vendyyoct@gmail.com,wulanp@fikom.untar.ac.id \\ Fakultas Ilmu Komunikasi Universitas Tarumanagara
}

\begin{abstract}
E-WOM is a message or information that comes from personal experience or consumer opinion on a product or service and is spread by word of mouth via the internet media. High $e$-WOM can create customer engagement. Customer engagement is an attitude towards a brand or company, which involves active consumer commitment through online media in the form of word-of-mouth activities, providing reviews, recommendations, and blogging that is driven by motivation. This study aims to measure the effect of e-WOM on customer engagement at Osbond Gym Bekasi. This research uses quantitative techniques with a survey method. Primary data were collected through distributing questionnaires to 85 respondents who are customers of Osbond Gym Bekasi. Data analysis used the Statistical Package for the Social Sciences with the SPSS for Windows 25 application. Based on the research results, it is known that there is a positive influence between e-WOM on customer engagement. E-WOM has an effect of $69.7 \%$ on customer engagement, while $30.3 \%$ is another factor
\end{abstract}

Keywords: customer engagement, e-wom, osbond gym bekasi

\begin{abstract}
Abstrak
E-WOM adalah suatu pesan atau informasi yang berasal dari pengalaman pribadi atau opini konsumen akan suatu produk atau jasa dan disebarkan dari mulut ke mulut melalui media internet. E-WOM yang tinggi dapat menciptakan customer engagement. Customer engagement merupakan suatu sikap terhadap merek atau perusahaan, yang melibatkan komitmen konsumen secara aktif melalui media online yang berupa aktivitas word-of-mouth, memberikan review, rekomendasi, dan blogging yang didorong oleh suatu motivasi. Penelitian ini bertujuan untuk mengukur pengaruh $e$-WOM terhadap customer engagement di Osbond Gym Bekasi. Penelitian ini menggunakan teknik kuantitatif dengan metode survei. Data primer dikumpulkan melalui penyebaran kuesioner kepada 85 responden yang merupakan pelanggan dari Osbond Gym Bekasi. Analisis data menggunakan Statistical Package for the Social Sciences dengan aplikasi SPSS for windows 25. Berdasarkan hasil penelitian, diketahui bahwa terdapat pengaruh positif antara $e$-WOM terhadap customer engagement. E-WOM memiliki pengaruh sebesar $69,7 \%$ terhadap customer engagement, sementara 30,3\% lainnya merupakan faktor lain.
\end{abstract}

Kata kunci: customer engagement, e-wom, osbond gym bekasi

\section{Pendahuluan}

Di jaman modern seperti saat ini, banyak cara orang melakukan kegiatan olahraga, baik yang dilakukan di luar ruangan maupun di dalam ruangan. Menurut Indosport, salah satu altivitas kesehatan yang saat ini sangat digemari oleh masyarakat adalah fitness (kebugaran). Hal ini dapat terlihat dari maraknya pusat- 
pusat kebugaran yang ada di berbagai wilayah, bahkan saat ini pun fitness centre telah umum ditemukan di pusat perbelanjaan atau mall. Pandemi yang sedang terjadi saat ini ternyata banyak merugikan pelaku bisnis, terutama pusat kebugaran. Beruntung, beberapa diantaranya sudah kembali beroperasi. Salah satunya adalah Osbond Gym Mega yang berlokasi di Bekasi.

Untuk mempertahankan pelanggan di masa pandemik, Osbond Gym Mega melakukan berbagai cara, salah starteginya adalah dengan $e$-WOM (e-WOM). EWOM didefinisikan sebagai suatu komunikasi yang berfungsi untuk saling bertukar informasi mengenai suatu produk atau jasa oleh setiap konsumen yang telah konsumsi, kepada konsumen lain yang tidak saling mengenal satu sama lain ataupun pernah bertemu sebelumnya (Adeliasari et al., 2014). Komunikasi dalam $e$-WOM dapat terjadi di dalam sebuah platform atau di berbagai media elektronik seperti forum diskusi online, newsgroup, blog, dan review sites dimana konsumen dapat membagikan pendapatnya mengenai suatu produk atau jasa kepada konsumen lain (Themba dan Mulala, 2013).

Ada tiga dimensi $e$-WOM, yakni intensitas (intensity), valence of opinion, dan konten (content) (Utami dan Saputri,2016). Perkembangan teknologi dan internet juga mempengaruhi customer engagement yang dulu menggunakan seperti kertas, forum diskusi, seminar dan sebagainya, sekarang dapat menggunakan media sosial. Customer engagement merupakan suatu sikap terhadap merek atau perusahaan, yang melibatkan komitmen konsumen dari sisi kognitif dan afektif secara aktif melalui media online yang berupa aktivitas word-of-mouth, membantu sesama konsumen, memberikan review, rekomendasi, dan blogging yang didorong oleh suatu motivasi (Sanjaya, 2020).

Peran e-WOM di customer engagement menjadi sangat penting karena iandapat memengaruhi perilaku pembelian konsumen. Pengaruh lainnya adalah reputasi bagi perusahaan, konsumen yang terlibat dapat memberikan kontribusi pada perusahaan dalam jangka panjang dan juga brand recognition, buktinya konsumen mengikuti dan berpartisipasi dalam komunitas merek dan mengikuti acara yang mendukung merek tersebut (Van Doorn et al, 2010). Berdasarkan penjelasan latar belakang tersebut, peneliti tertarik untuk melihat apakah ada pengaruh antara $e$-WOM terhadap customer engagement.

Penelitian ini memiliki persamaan dengan penelitian Brigitta Novilia dan Riris Loisa (2019) dengan judul Pengaruh e-WOM di Instagram Terhadap Loyalitas Pelanggan Kopi Janji Jiwa. Persamaannnya adalah sama-sama meneliti tentang $e$ Wom. Penelitian Brigitta Novilia dan Riris Loisa membuktikan bahwa terdapat pengaruh $e$-WOM terhadap loyalitas pelanggan. Karenanya, peneliti juga ingin mengetahui apakah terdapat pengaruh antara $e$-Wom terhadap customer engagement. Maka dari itu peneliti menetapkan judul dalam penelitian ini adalah "Pengaruh $e$ Wom terhadap Customer Engagement Pelanggan Osbond Gym Bekasi dalam Penerapan Protokol Kesehatan Covid - 19.

\section{Metode Penelitian}

Penelitian ini bertujuan mengetahui pengaruh e-WOM terhadap customer engagement. Penelitian ini menggunakan metode penelitian kuantitatif dengan teknik survei. Metode survei adalah penelitian yang dilakukan untuk mengumpulkan data atau informasi yang dilakukan dengan cara mengajukan daftar pertanyaan atau pernyataan kepada responden. Penggalian data dapat dilakukan melalui kuesioner 
dan wawancara (Sujarweni, 2019). Populasi adalah wilayah generalisasi yang terdiri atas objek-subjek yang mempunyai kualitas dan karakteristik tertentu yang ditetapkan oleh peneliti untuk dipelajari, dianalisis, dan ditarik kesimpulan (Sugiyono, 2017). Populasi yang dipakai pada penelitian ini adalah seluruh pelanggan Osbond GYM Mega Bekasi.

Sampel adalah bagian dari sejumlah karakteristik yang dimiliki oleh populasi yang digunakan untuk penelitian. Bila populasi besar, peneliti tidak mungkin mengambil semua untuk penelitian missal karena terbatasnya dana, tenaga, dan waktu, maka peneliti dapat menggunakan sampel yang diambil dari populasi itu. Apa yang dipelajari dari sampel, kesimpulannya akan dapat diberlakukan untuk populasi (Sujarweni, 2019).

Menurut Charvia dan Erdiansyah (2020), untuk menentukan jumlah sampel dalam penelitian, banyaknya responden yang digunakan untuk penelitian bergantung pada banyaknya jumlah indikator penelitian dikali 5. Dalam penelitian ini, peneliti menyebarkan kuesioner kepada 85 responden yang merupakan pelanggan Osbond GYM Mega Bekasi. Penyebaran kuesioner dilakukan melalui google form untuk mendapatkan data yang sesuai dengan yang diharapkan oleh peneliti.

Penelitian ini menggunakan metode accidental sampling yang merupakan teknik untuk menentukan sampel dengan kebetulan yaitu siapa saja yang dijadikan responden secara kebetulan bertemu dan dijadikan peneliti sebagai sampel karena cocok untuk dijadikan sebagai sumber data (Martono, 2012). Penelitian ini diukur dengan skala likert kemudian diolah menggunakan software SPSS versi 25 untuk menguji validitas, reliabilitas, korelasi, dan hipotesis.

\section{Hasil Temuan dan Diskusi}

Dalam penelitian ini, peneliti menyebarkan kuesioner kepada 85 responden dan mendapatkan data berupa jenis kelamin. Sebanyak 45 orang $(54,7 \%)$ responden berjenis kelamin laki-laki dan 40 orang $(45,3 \%)$ responden berjenis kelamin perempuan. Sedangkan secara usia, responden di dominasi pada usia 18 - 22 tahun sebanyak 62 orang $(72,9 \%)$, kemudian responden berusia $23-27$ tahun sebanyak 18 orang $(21,2 \%)$, responden berusia 28 - 32 tahun sebanyak 3 orang $(3,5 \%)$, dan responden berusia 33 - 37 tahun sebanyak 2 orang $(2,4 \%)$. Maka dapat disimpulkan bahwa mayoritas usia responden dalam penelitian ini adalah 18 - 22 tahun.

Setelah melakukan uji validitas dengan menggunakan aplikasi SPSS for windows versi 25, maka berikut hasil dari uji validitas. Dalam hasil uji validitas, diketahui bahwa butir-butir indikator atau pernyataan dari seluruh variabel dinyatakan valid karena seluruhnya memiliki nilai diatas 0,2 . Kemudian dalam hasil uji reliabilitas, diketahui bahwa setiap pernyataan dalam kuisoner dikatakan reliabel karena memiliki nilai Cronbach's Alpha di atas 0,6. Dan dalam penelitian ini, peneliti menggunakan uji One Sample Kolmogorov Smirnov yang ada pada aplikasi SPSS Ver 25. Hasil analisis menunjukan bahwa ada nilai signifikansi sebesar 0,219. Hasil tersebut menyatakan bahwa distribusi data berdistribusi secara normal karena nilai signifikansi $>0,05$. Dalam penelitian ini, hasil mean score yang ditunjukkan pada pengolahan data SPSS for windows versi 25, diketahui bahwa pernyataan tentang responden memperoleh informasi tentang promosi yang ditawarkan oleh Osbond GYM Bekasi memperoleh nilai mean yang paling besar dengan nilai 4.2000 untuk variabel $\mathrm{X}$, kemudian untuk variabel $\mathrm{Y}$ nilai mean terbesar berada pada 
pernyataan responden menceritakan pengalaman dan perasaan mengenai Osbond GYM Bekasi, dengan nilai mean 4.2706.

\begin{tabular}{|c|c|c|c|c|c|c|}
\hline & \multicolumn{6}{|c|}{ Tabel 1. Uji T } \\
\hline & Model & \multicolumn{2}{|c|}{$\begin{array}{c}\text { Unstandardized } \\
\text { Coefficients }\end{array}$} & $\begin{array}{c}\text { Standardized } \\
\text { Coefficients }\end{array}$ & $\mathrm{t}$ & Sig. \\
\hline \multirow[t]{3}{*}{1} & (Constant) & $\mathrm{B}$ & $\begin{array}{c}\text { Std. } \\
\text { Error }\end{array}$ & Beta & & \\
\hline & \multirow[t]{2}{*}{ E-Wom } & 5,643 & 2,909 & & 1,940 & 0,056 \\
\hline & & 1,603 & 0,166 & 0,835 & 13,833 & 0,000 \\
\hline
\end{tabular}

Sumber: Hasil Pengolahan Data SPSS Versi 25

Tabel 1 menunjukkan dari hasil analisis data diketahui bahwa nilai $\mathrm{t}=13,833$ dan tingkat signifikansi $=0,00<0,05$. Karena nilai $\mathrm{p}$ lebih kecil dari 0,05 , maka $\mathrm{H}_{0}$ ditolak dan $\mathrm{H}_{\mathrm{a}}$ diterima, yang berarti terdapat pengaruh yang signifikan antara $e$ WOM terhadap customer engagement.

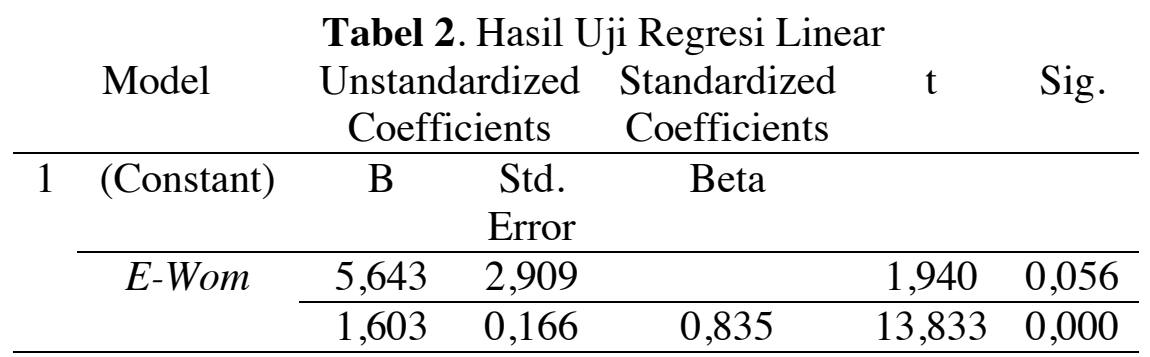

Sumber: Hasil Pengolahan Data SPSS Versi 25

Dengan keterangan $\mathrm{Y}=$ customer engagement dan $\mathrm{X}=e$-WOM. Berdasarkan persamaan regresi linear pada tabel 5, dapat dijabarkan sebagai berikut:

1. Nilai Y (customer engagement) akan tetap sebesar 5,643 konstanta jika nilai X (eWOM) tidak mengalami perubahan, baik peningkatan maupun penurunan.

2. Jika nilai $\mathrm{X}(e-W O M)$ mengalami peningkatan nilai sebesar 1 satuan, maka nilai $\mathrm{Y}$ (customer engagement) mengalami peningkatan sebesar 1,603 menjadi 7,246.

Tabel 3. Hasil Uji Korelasi

\begin{tabular}{ccccc}
\hline Model & $\mathrm{R}$ & $\mathrm{R}$ Square & $\begin{array}{c}\text { Adjusted R } \\
\text { Square }\end{array}$ & $\begin{array}{c}\text { Std. Error of } \\
\text { the Estimate }\end{array}$ \\
\hline 1 & $.835^{\mathrm{a}}$ & .697 & .694 & 3,689 \\
\hline
\end{tabular}

Sumber: Hasil Pengolahan Data SPSS Versi 25

Dari hasil perhitungan tabel 3 , didapati bahwa nilai koefisien korelasi $\mathrm{R}$ sebesar 0,835 yang berada di antara interval $0,80-0,100$ artinya $e$-WOM mempunyai hubungan yang sangat kuat terhadap customer engagement.

Tabel 4. Hasil Uji Determinasi

\begin{tabular}{ccccc}
\hline Model & $\mathrm{R}$ & $\mathrm{R}$ Square & $\begin{array}{c}\text { Adjusted R } \\
\text { Square }\end{array}$ & $\begin{array}{c}\text { Std. Error of } \\
\text { the Estimate }\end{array}$ \\
\hline 1 & $.835^{\mathrm{a}}$ & .697 & .694 & 3,689 \\
\hline
\end{tabular}

Sumber: Hasil Pengolahan Data SPSS Versi 25 
Dari hasil perhitungan tabel 4, didapati nilai pada tabel R Square sebesar 0,697 mengartikan bahwa 69,7\% customer engagement dipengaruhi oleh $e$-WOM sementara sisanya 30,3\% (100\%-69,7\%) dipengaruhi oleh faktor lain.

Secara keseluruhan hasil penelitian ini menunjukkan adanya pengaruh antara $e$-WOM terhadap customer engagement. Hal ini ditunjukkan dengan hipotesis dalam penelitian diterima, artinya bahwa ada pengaruh positif antara $e$-WOM terhadap customer engagement. Hal itu ditunjukkan pada hasil uji regresi linear sederhana yang dimana nilai koefisien regresi bernilai positif. Menurut Themba dan Mulala (2013), komunikasi dalam $e$-WOM dapat terjadi di dalam sebuah platform atau di berbagai media elektronik seperti forum diskusi online, newsgroup, blog, dan review sites dimana konsumen dapat membagikan pendapatnya mengenai suatu produk atau jasa kepada konsumen lain.

Sebagian besar responden setuju dan sangat setuju mengenai responden merekomendasikan kepada orang lain untuk menggunakan Osbond GYM Bekasi sebagai tempat GYM mereka, dengan persentase sebesar $67.1 \%$ untuk setuju dan $28,2 \%$ untuk sangat setuju. Menurut So et al (2014), identification dapat menjelaskan hubungan antar perusahaan atau merek dan konsumen. Hubungan kuat antar konsumen dan perusahaan berdasarkan identitas konsumen dengan perusahaan yang membantu memenuhi kebutuhan konsumen. Berdasarkan persepsi konsumen, identification menjadi identitas kesatuan konsumen dengan merek tersebut. Dari analisis hasil penelitian diketahui bahwa sebanyak $67,1 \%$ dan $24,7 \%$ dari jumlah responden memilih setuju dan sangat setuju mengenai responden merasa Osbond GYM Bekasi sesuai dengan identitas diri mereka. Ini menunjukkan bahwa Osbond GYM Bekasi telah memiliki hubungan yang kuat dengan para konsumennya, sehingga konsumen merasa Osbond GYM Bekasi sesuai dengan identitas mereka.

Adanya $e$-WOM mengenai Osbond Gym Bekasi, masyarakat di daerah bekasi menjadi lebih mengetahui tentang Osbond Gym Bekasi, sehingga akan meningkatkan customer engagement dan menarik perhatian masyarakat mengenai hal-hal yang bersangkutan dengan Osbond Gym Bekasi. Menurut Van Doom et al (Sanjaya, 2020) peran e-WOM di customer engagement menjadi sangat penting karena dapat mempengaruhi perilaku pembelian konsumen dan juga pada konsumen lainnya. Selain itu pengaruh lainnya adalah reputasi bagi perusahaan, konsumen yang terlibat dapat memberikan kontribusi pada perusahaan dalam jangka panjang dan juga brand recognition, buktinya seperti para konsumen mengikuti dan berpartisipasi dalam komunitas merek dan mengikuti acara yang mendukung merek tersebut.

Konsumen Osbond Gym Bekasi telah memberikan pengaruh bagi Osbond Gym Bekasi yaitu di bagian reputasi, baik melalui secara langsung maupun percakapan yang terjadi di media sosial. Konsumen juga telah memberikan kontribusi seperti mengikuti dan berpartisipasi dalam acara atau komunitas yang telah dibuat oleh Osbond Gym Bekasi.

Berdasarkan hasil penelitian dan pembahasan diatas, dapat disimpulkan bahwa $e$-WOM yang kuat dapat memengaruhi customer engagement, sebab hasil dari koefisien korelasi dan analisis linear sederhana menyatakan bahwa $e$-WOM memiliki pengaruh yang sangat kuat terhadap customer engagement dan bernilai positif.

\section{Simpulan}

Penelitian ini menyimpulkan bahwa e-WOM terhadap customer engagement memiliki hubungan yang sangat kuat. Berdasarkan hasil uji korelasi, diketahui bahwa 
nilai korelasi berada di interval 0,80 - 0,100 yang berarti $e$-WOM memiliki peranan yang sangat kuat terhadap customer engagement dan bersifat positif. Kemudian dari hasil determinasi menunjukkan bahwa $e$-WOM memiliki peranan sebesar $69,7 \%$ terhadap customer engagement. Sementara sisanya 30,3\% (100\%-69,7\%) dipengaruhi oleh faktor lain. Dengan demikian, semakin tinggi suatu $e$-WOM maka customer engagement suatu perusahaan meningkat. Begitu juga sebaliknya, semakin rendah suatu $e$-WOM maka customer engagement juga semakin menurun.

Berdasarkan kuesioner yang telah disebarkan, data pernyataan sebanyak 17 butir pernyataan dikatakan valid, karena semua pernyataan yang telah disebarkan memiliki nilai diatas 0,2 dan mendukung hipotesis bahwa terdapat pengaruh antara $e$ WOM terhadap customer engagement.

\section{Ucapan Terima Kasih}

Ucapan terima kasih diberikan kepada responden penelitian dan seluruh pihak yang membantuk peneliti dalam menyempurnakan penelitian ini, khususnya kepada Fakultas Ilmu Komunikasi Universitas Tarumanagara.

\section{Daftar Pustaka}

Adeliasari, V. I. (2014). Electronic Word-Of-Mouth (E-Wom) Dan Pengaruhnya Terhadap Keputusan Pembelian Di Restoran Dan Kafe Di Surabaya. Jurnal Hospitality dan Manajemen Jasa, 2(2), 218-230.

Charvia, K., \& Erdiansyah, R. (2020). Pengaruh E-WOM dan Brand Experience Terhadap Brand Trust (Studi Terhadap Pengguna OVO di Jakarta). Prologia. 4(2), 237-244.

Martono, N. (2012). Metode Penelitian Kuantitatif Analisis Isi dan Analisis Data Sekunder. Jakarta: PT. RajaGrafindo Persada.

Sanjaya, Linda. (2020). Analisis Pengaruh Content Marketing Pada Customer Value dan Customer Engagement Serta Dampaknya Terhadap Repeat Purchase Pada PegiPegi di Surabaya. Jurnal Strategi Pemasaran, 7(1).

Sugiyono. (2017). Metode Penelitian Kuantitatif, Kualitatif, dan R\&D. Bandung: Alfabeta.

Sujarweni, Wiratna. (2019). Metodologi Penelitian. Yogyakarta: PT. Pustaka Baru.

Themba, G. M. M. (2013). Brand-Related eWOM and Its Effects on Purchase Decisions: An Empirical Study of University of Botswana Students. International Journal of Business and Management, 8(8), 31-40.

Utami, D. W., \& Saputri, M. E. (2016). Pengaruh E-WOM (E-Wom) Terhadap Keputusan Pembelian Pada Konsumen Café Roti Gempol Dan Kopi Anjis Bandung. Journal e-Proceeding of Management, 3(2), 1-6. 